\title{
Strain Differences in the Reverse Tolerance to Methamphetamine and Changes in Catecholaminergic Neurons in Mice
}

\author{
Tetsu HAYASHI, Makizo HIRABAYASHI and Sakutaro TADOKORO \\ Behavioral Research Institute, Gunma University School of Medicine, \\ Maebashi 371 , Japan \\ Accepted March 20, 1987
}

\begin{abstract}
The effect of methamphetamine (MAP) on ambulatory activity and neurochemical changes in catecholaminergic neurons in the brain were investigated in $\mathrm{dd}$ and $\mathrm{C} 57 \mathrm{BL} / 6$ strains of male mice. The mice were given repeatedly MAP at $2 \mathrm{mg} / \mathrm{kg}$, s.c., 10 times at a fixed interval of 4 days. Single MAP markedly increased the ambulatory activity in both strains of mice. The ambulationincreasing effect was progressively enhanced without accompanying stereotyped behaviors when the drug was repeatedly given. The dd mice showed higher susceptibility not only to single MAP but also to the enhancing effect of the drug (reverse tolerance) than the $\mathrm{C} 57 \mathrm{BL} / 6$ mice. On the other hand, non-treated $\mathrm{dd}$ mice exhibited lower maximum densities of ${ }^{3} \mathrm{H}$-spiperone binding sites in the striatum and ${ }^{3} \mathrm{H}$-WB4101 binding sites in the cortex and hippocampus than nontreated $\mathrm{C} 57 \mathrm{BL} / 6$ mice. In contrast, the dd mice exhibited higher noradrenaline turnover than the $\mathrm{C} 57 \mathrm{BL} / 6$ mice in the brain regions examined. The repeated administration of MAP produced decrease in the densities of both ${ }^{3} \mathrm{H}$-spiperone and ${ }^{3} \mathrm{H}$-WB4101 binding sites in the corresponding regions with increase in catecholamine turnover in dd mice. However, the similar changes were observed only in ${ }^{3} \mathrm{H}-$ WB4101 binding sites and noradrenaline turnover in $\mathrm{C} 57 \mathrm{BL} / 6$ mice. These results suggest that the ambulation-increasing effect of MAP is positively correlated with catecholamine turnover, while it was correlated negatively with the densities of catecholamine binding sites. Furthermore, the enhancing effect of MAP is supposed to have been partially elicited by changes in brain catecholaminergic systems, in particular an increase in catecholamine turnover. Strain difference in the enhancing effect of MAP may be partially caused by different regional sensitivity to the drug.
\end{abstract}

It has been reported that inbred strains of mice often exhibit marked diversity in behavioral properties $(1,2)$, susceptibility to psychotropic drugs (3-6) and neurochemical characteristics (7-11). These strain differences have provided a useful tool for investigating correlations between behavioral and neurochemical parameters. Thus, we have systematically investigated the strain differences in behavioral properties and susceptibility to several psychotropic drugs using 6 strains of mice $(2,12)$.

In the present experiment, we investigated neurochemical backgrounds underlying the strain differences in the enhancement of the ambulation-increasing effect of methamphetamine (reverse tolerance) in dd and C57BL/ 6 mice.

\section{Materials and Methods}

Animals: The experimental animals used were male mice of the $d d$ and $C 57 \mathrm{BL} / 6$ strains. The dd strain mice were bred for more than 30 years by brother-sister mating at the Institute of Experimental Animal Research, Gunma University School of Medicine, and the C57BL/6 strain mice were supplied by Charles River Japan. Inc. (Atsugi). These mice were housed in groups of 10 in plexiglass cages of $30(W) \times 20(D) \times$ 
$10(\mathrm{H}) \mathrm{cm}$ with a wooden-flake floor mat (White-Flake: Charles River Japan, Inc., Atsugi) and were given free access to a solid diet MF (Oriental Yeast Co., Tokyo) and tap water. The animal room where the cages were set up was artificially illuminated by fluorescent lamps with a $12 \mathrm{hr}$ light-dark cycle (light on 7:00-19:00), and room temperature was controlled to $24 \pm 2{ }^{\circ} \mathrm{C}$. All mice were aged $9-10$ weeks at the start of the experiment.

Apparatus: The ambulatory activity of mice was measured by an ambulometer (AMB-M20, O'hara and Co., Ltd., Tokyo). The principle of the device and the measurement method have been described in details by Hirabayashi et al. (13). Briefly, a mouse was placed in a tilting-type round activity cage of $18 \mathrm{~cm}$ in diameter and $20 \mathrm{~cm}$ in height. Any slight tilt of the activity cage caused by horizontal movement of the animal was detected by microswitches attached to the cage. Total activity counts in each $10 \mathrm{~min}$ segment were automatically recorded for 30 min in preinjection periods and for $180 \mathrm{~min}$ following the drug administration.

Drug used and administration schedules: The drug used was methamphetamine hydrochloride (MAP) (Philopon ${ }^{\circledR}$, Dainippon Pharmaceutical Co., Ltd., Osaka). MAP was dissolved in a physiological saline vehicle, and the volume administered was made up to $10 \mathrm{ml} / \mathrm{kg}$ of body weight. The dose tested was expressed in terms of the salt form.

Two groups (50 animals/group) of nontreated dd mice were repeatedly given saline and MAP at $2 \mathrm{mg} / \mathrm{kg}$. s.c., respectively, 10 times at a fixed interval of 4 days in the activity cages, and the ambulatory activity was recorded after each drug administration. The same experiment was performed for nontreated $\mathrm{C} 57 \mathrm{BL} / 6$ mice. In all experiments. administration of saline or MAP was carried out between 10:00-13:00 of the light periods.

Receptor assay: Thirty non-treated mice were sacrificed by decapitation, and the brains were rapidly removed. Each brain was dissected into 4 regions (cerebral cortex. striatum, hippocampus and brain stem) on an ice cold petri dish according to the method of Growinski and Iversen with a minor modification (14). The animals given repeatedly saline (30 animals) or MAP (30 animals) were killed by decapitation at 10 days after the last administration, and each brain was dissected in the same way.

The ${ }^{3} \mathrm{H}$-spiperone (SPP) $(18 \mathrm{ci} / \mathrm{mmol}$, Amersham Japan, Tokyo) binding test was carried out essentially as described by Usdin et al. (15). Fresh tissues were homogenized by an ultrasonic homogenizer (US-150. Nissei Co., Ltd., Tokyo) in Tris- $\mathrm{HCl}$ buffer ( $50 \mathrm{mM}, \mathrm{pH}=7.7$ ) and centrifuged at 50,000 $\mathrm{g}$ for $20 \mathrm{~min}$. The resulting pellet was resuspended in another portion of buffer and centrifuged again. Finally, the pellet was resuspended in Tris- $\mathrm{HCl}$ buffer $(50 \mathrm{mM}$. $\mathrm{pH}=7.1$ ) containing $0.1 \%$ ascorbic acid. Particulate suspension containing about 0.5 mg protein was used for ${ }^{3} \mathrm{H}$-SPP binding tests (final concentrations of $0.11-2 \mathrm{nM}$ ). The reaction mixture $(1 \mathrm{ml})$ was incubated at $37^{\circ} \mathrm{C}$ for $20 \mathrm{~min}$ in the presence of ketanserin (final concentration of $0.1 \mu \mathrm{M}$. ketanserin tartrate, Kyowa Hakko, Tokyo) and was then filtered through a Whatman GF/B filter under vacuum. Ketanserin, a $S_{2}$-serotonin blocker, was used for the $D_{2}$-dopamine receptor binding studies by ${ }^{3} \mathrm{H}-\mathrm{SPP}$, because ${ }^{3} \mathrm{H}$-SPP simultaneously labels 5 -HT receptors as well as dopamine receptors in the brain, particularly in the frontal cortex (16). dButaclamol (final concentration $1 \mu \mathrm{M}$, butaclamol hydrochloride, Research Biochemicals, Inc. Wayland) was used to assess nonspecific binding. The filter was rinsed three times with $5 \mathrm{ml}$ ice cold Tris- $\mathrm{HCl}$ buffer $(50 \mathrm{mM}, \mathrm{pH}=7.7)$. The filters were placed in $10 \mathrm{ml}$ of liquid scintillation cocktail and counted $24 \mathrm{hr}$ later by liquid scintillation spectrometry (LSC-673, Aloka, Tokyo).

${ }^{3} \mathrm{H}-$ WB4101 binding assay: ${ }^{3} \mathrm{H}-\mathrm{WB} 4101$. $\left\{2-\left(\left[2^{\prime}, 6^{\prime}\right.\right.\right.$-dimethoxy] phenoxyethylamino) methyl benzodioxan) $(27 \mathrm{Ci} / \mathrm{mmol}$. Amersham Japan, Tokyo) binding tests were carried out by the method of U'Prichard et al. (17). ${ }^{3} \mathrm{H}$-WB4101 has been used as an $\alpha_{1}$ noradrenaline receptor marker in the brain (18). Particulate suspension was obtained in the same way as described above. The reaction mixture $(1 \mathrm{ml})$ consisted of particulate suspension (about $0.5 \mathrm{mg}$ protein). ${ }^{3} \mathrm{H}-$ WB4101 (final concentrations of $0.11-2$ $\mathrm{nM}$ ) and phentolamine (final concentration 
of $0.5 \mathrm{mM}$. Regitin ${ }^{(\mathbb{R})}$, Japan Ciba-Geigy. Ltd.). Phentolamine was used to determine nonspecific binding. The mixture was incubated at $25^{\circ} \mathrm{C}$ for $20 \mathrm{~min}$, followed by filteration through a Whatman GF/B filter under vacuum. The filter was rinsed with Tris- $\mathrm{HCl}$ buffer $(50 \mathrm{mM}, \mathrm{pH}=7.7)$, followed by measurement of radioactivity in the same way as described above.

The ${ }^{3} \mathrm{H}$-SPP binding test was carried out for the striatum, and the ${ }^{3} \mathrm{H}-\mathrm{WB} 4101$ binding test performed for the cerebral cortex and hippocampus, because a significant decrease in the $B_{\max }$ value of ${ }^{3} \mathrm{H}$-SPP binding sites was observed in the striatum, whereas significant decreases in ${ }^{3} \mathrm{H}$-WB4101 binding sites were detected in the cortex and hippocampus in the previous study on the enhancing effect of ambulatory activity of MAP (19). Protein concentration was determined by the method of Lowry et al. (20).

Catecholamine assay: Twenty non-treated mice of each strain (2 mice/assay) were decapitated after enzyme inactivation by microwave irradiation at $5 \mathrm{~kW}$ for $1.5 \mathrm{sec}$ (TMW-6402A, Toshiba, Tokyo), and the brains were rapidly removed for subsequent catecholamine analysis. In regard to the animals given saline or MAP repeatedly, twenty animals of each strain (2 mice/assay) were decapitated on the 10th day after termination of the repeated administration. Regional levels of dopamine (DA), noradrenaline (NA) and 3,4-dihydroxyphenylacetic acid (DOPAC) were measured by highperformance liquid chromatography ( $L-5000$. Yanaco, Kyoto) with an electrochemical detector (VMD-501. Yanaco, Kyoto) using the technique of Keller et al. (21), while 4hydroxy-3-methoxy phenylglycol (MHPG) levels were measured essentially by the method of Semba and Takahashi (22). DA and DOPAC levels were determined for the striatum where the ${ }^{3} \mathrm{H}$-SPP binding test was carried out, while NA and MHPG levels were measured in the cortex and hippocampus where the $3 \mathrm{H}-\mathrm{WB} 4101$ binding test was done.

Statistical analysis: Statistical significance of differences between groups was analyzed by one- or two-way ANOVA followed by Student's $t$-test. The differences were con- sidered to be significant when the $P$ value was equal or less than 0.05 .

\section{Results}

Behavioral observation: Ambulatory activity in the preinjection period in nontreated $d d$ and $\mathrm{C} 57 \mathrm{BL} / 6$ mice were $145.4 \pm$ 52.0 and $142.5 \pm 10.5$ counts $/ 30 \mathrm{~min}$, respectively, and no significant difference was observed between the strains. MAP at $2 \mathrm{mg} /$ $\mathrm{kg}$ increased the ambulatory activity in mice of both strains for about $180 \mathrm{~min}$ with the maximum peak at 50-60 min. However, total activity counts $/ 180 \mathrm{~min}$ in the $1 \mathrm{st}$ administration in dd mice were about 2 times as high as those in C57BL/6 mice, and significant difference in susceptibility to the drug was observed between the strains as shown in

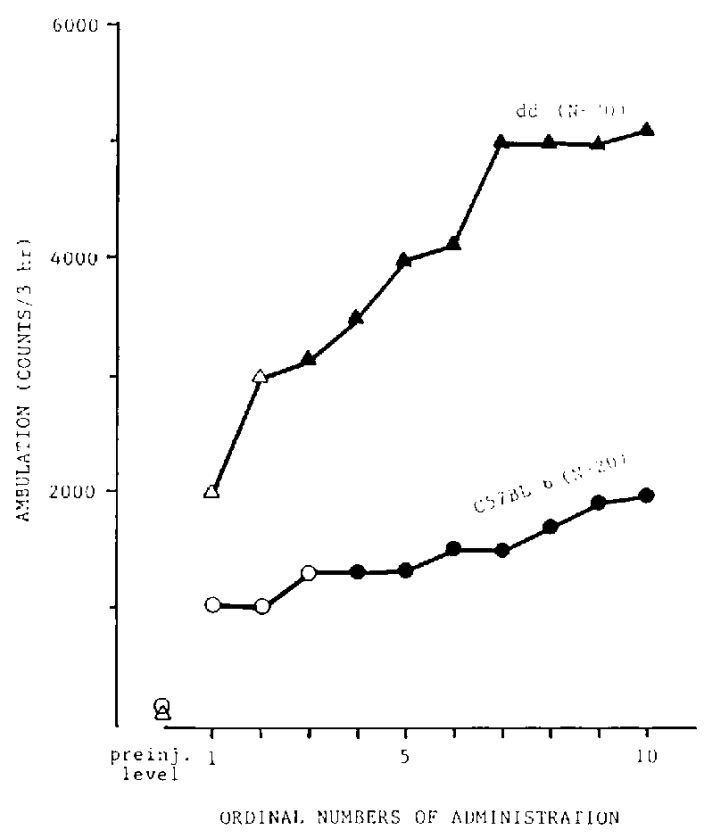

Fig. 1. Changes in ambulation-increasing effect of methamphetamine $(2 \mathrm{mg} / \mathrm{kg}$ ) given repeatedly at a fixed interval of 4 days in dd and $\mathrm{C} 57 \mathrm{BL} / 6$ mice. Progressive enhancement of the ambulationincreasing effect was observed in both strains of mice when the drug was given repeatedly. The mean total activity counts for $3 \mathrm{hr}$ in the $1 \mathrm{st-10th}$ administrations were significantly higher in dd mice than those in $\mathrm{C} 57 \mathrm{BL} / 6$ mice. $\triangle \mathrm{dd}$ mice. $\bigcirc \mathrm{C} 57 \mathrm{BL} / 6$ mice. Closed symbols $\boldsymbol{A}$. represent significant difference from the corresponding levels in the first administration. "N" represents numbers of animals. 
Fig. 1.

The ambulation-increasing effect of MAP was progressively enhanced in both strains without accompanying stereotyped behaviors when the drug was repeatedly given at a fixed interval of 4 days. As shown in Fig. 1, mean total activity counts $/ 180 \mathrm{~min}$ obtained in the 3rd and 4th administrations and thereafter in dd and C57BL/6 mice, respectively, were significantly higher when compared with the corresponding counts obtained in the 1st administration. In addition, the mean total activity counts $/ 180 \mathrm{~min}$ in the $1 \mathrm{st}-10 \mathrm{th}$ administrations were significantly higher in dd mice than in $\mathrm{C} 57 \mathrm{BL} / 6$ mice. Thus, marked strain difference in the ambulation-increasing effect was observed after repeated administration as shown in Fig. 1. Ambulatory activities in the preinjection period were scarcely affected by repeated saline administration in both strains (data are not shown).

Receptor binding assay: The $B_{\max }$ value of ${ }^{3} \mathrm{H}$-SPP binding sites in the striatum of nontreated dd mice was significantly lower than that of non-treated $\mathrm{C} 57 \mathrm{BL} / 6$ mice. $\mathrm{B}_{\max }$ values of ${ }^{3} \mathrm{H}$-WB4101 binding sites in the cortex and hippocampus of non-treated dd mice were also significantly lower than those of non-treated C57BL/6 mice as shown in Table 1 . On the other hand, the $K_{d}$ value of ${ }^{3} \mathrm{H}-\mathrm{WB} 4101$ binding sites in the hippocampus of non-treated dd mice was significantly lower than that of non-treated C57BL/6 mice. However, no significant differences in the $\mathrm{K}_{\mathrm{a}}$ values of ${ }^{3} \mathrm{H}$-SPP binding sites in the striatum and in those of ${ }^{3} \mathrm{H}$-WB4101 binding sites in the cortex were detected between the two strains (Table 1).

No significant differences in $B_{\max }$ values of saline-treated mice of both strains were observed when compared with those of nontreated mice of both strains (Table 1).

Significant decrease in the $B_{\max }$ value of ${ }^{3} \mathrm{H}$-SPP binding sites in the striatum was detected in MAP-treated dd mice when compared with the value obtained in salinetreated dd mice (Tabie 1). The $B_{\max }$ value of ${ }^{3} \mathrm{H}-$ WB4101 binding sites was significantly decreased in the cortex of MAPtreated dd mice, but no change in the value was detected in the hippocampus. On the other hand, no significant difference in $B_{\max }$ values of ${ }^{3} \mathrm{H}$-SPP binding sites in the striatum was detected between saline- and MAP-treated $\mathrm{C} 57 \mathrm{BL} / 6$ mice. However, $\mathrm{B}_{\max }$ values of ${ }^{3} \mathrm{H}-$ WB4101 binding sites decreased significantly in the cortex and hippocampus of MAP-treated C57BL/6 mice when compared with those in saline-treated C57BL/6 mice (Table 1).

There were statistically significant differences in the $\mathrm{B}_{\max }$ value of $3 \mathrm{H}$-SPP binding sites in the striatum and the same values of ${ }^{3} \mathrm{H}$-WB4101 binding sites in the cortex and hippocampus between saline-treated $\mathrm{dd}$ and C57BL/6 mice.

The $B_{\max }$ value of ${ }^{3} \mathrm{H}$-SPP binding sites in the striatum and the same value of ${ }^{3} \mathrm{H}$ WB4101 binding sites in the cortex of MAPtreated dd mice were significantly lower when compared with those of the corresponding binding sites of MAP-treated C57BL/6 mice. However, no significant difference in $B_{\max }$ value of ${ }^{3} \mathrm{H}$-WB4101 binding sites in the hippocampus was detected between MAPtreated dd and C57BL/6 mice.

$K_{d}$ values in saline-treated mice of both strains did not differ significantly from those in non-treated mice of both strains in any region (Table 1). No significant differences in $K_{d}$ values of MAP-treated dd mice were observed in any region when compared with those of saline-treated dd mice. On the other hand, $K_{u}$ values in MAP-treated C57BL/6 mice tended to increase in all regions examined. However, no significant differences were detected statistically between salineand MAP-treated C57BL/6 mice (Table 1). There were no significant differences in $K_{a}$ values in any region, not only between saline-treated $\mathrm{dd}$ and $\mathrm{C} 57 \mathrm{BL} / 6$ mice, but also between MAP-treated dd and C57BL/6 mice (Table 1).

Catecholamine assay: DOPAC/DA ratio (DA turnover) in the striatum tended to be higher in non-treated dd mice than that in non-treated C57BL/6 mice. However, no significant difference in the turnover was detected statistically between the strains. On the other hand. MHPG/NA ratios (NA turnover) in the cortex and hippocampus were significantly higher in non-treated dd mice when compared with those in non-treated C57BL/6 mice as shown in Fig. 2. 
Table 1. Effect of repeated administration of saline or methamphetamine $(2 \mathrm{mg} / \mathrm{kg})$ on saturation constants for specific bindings of ${ }^{3} \mathrm{H}$-spiperone and ${ }^{3} \mathrm{H}$ WB4101, respectively, in mouse brain regions

\begin{tabular}{|c|c|c|c|c|c|}
\hline \multirow{2}{*}{ Strains } & \multirow{2}{*}{ Treatments } & \multirow{2}{*}{ Constants } & ${ }^{3} \mathrm{H}$-Spiperone & \multicolumn{2}{|c|}{${ }^{3} \mathrm{H}-\mathrm{WB} 4101$} \\
\hline & & & Striatum & Cortex & Hippocampus \\
\hline \multirow{6}{*}{$d d$} & \multirow[t]{2}{*}{ Non-treated $(N=30)$} & $\mathrm{B}_{\mathrm{m} t \mathrm{x}}$ (fmol/mg protein) & $69.4 \pm 15.5^{:}$ & $79.0 \pm 5.0^{\mathrm{a}}$ & $69.0 \pm 13.0^{\mathrm{a}}$ \\
\hline & & $K_{d}(n M)$ & $0.78 \pm 0.10$ & $0.82 \pm 0.20$ & $0.64 \pm 0.11^{u}$ \\
\hline & Saline-treated $(N=30)$ & $\mathrm{B}_{\max }$ & $77.0 \pm 19.2^{\circ}$ & $80.7 \pm 6.7^{c}$ & $73.7 \pm 18.3^{c}$ \\
\hline & $(10 \mathrm{ml} / \mathrm{kg} / 4$ days $\times 10)$ & $K_{t i}$ & $0.71 \pm 0.15$ & $0.96 \pm 0.21$ & $0.55 \pm 0.09$ \\
\hline & MAP-treated $(N=30)$ & $B_{\text {IIan }}$ & $33.6 \pm 6.6^{b, c}$ & $36.2 \pm 2.81, c$ & $48.6 \pm 5.7$ \\
\hline & $(2 \mathrm{mg} / \mathrm{kg} / 4$ days $\times 10)$ & $K_{1}$ & $0.78 \pm 0.13$ & $0.94 \pm 0.12$ & $0.66 \pm 0.15$ \\
\hline & Non-treated $(N=30)$ & Bmax (fmol/mg protein) & $145.4 \pm 18.8$ & $169.9 \pm 13.9$ & $205.3 \pm 15.7$ \\
\hline & & $K_{t}(n M)$ & $0.86 \pm 0.13$ & $1.03 \pm 0.17$ & $1.31 \pm 0.13$ \\
\hline \multirow[t]{4}{*}{$\mathrm{C} 57 \mathrm{BL} / 6$} & Saline-treated $(N=30)$ & $\mathrm{B}_{\max }$ & $138.8 \pm 25.0$ & $167.0 \pm 19.3$ & $208.8 \pm 21.6$ \\
\hline & $(10 \mathrm{ml} / \mathrm{kg} / 4$ days $\times 10)$ & $K_{d}$ & $0.79 \pm 0.16$ & $1.06 \pm 0.23$ & $1.29 \pm 0.18$ \\
\hline & MAP-treated $(N=30)$ & $B_{\max }$ & $124.9 \pm 21.7$ & $103.8 \pm 13.3^{k}$ & $74.8 \pm 15.8^{b}$ \\
\hline & $(2 \mathrm{mg} / \mathrm{kg} / 4$ days $\times 10)$ & $\mathrm{K}_{\mathrm{d}}$ & $2.37 \pm 0.62$ & $1.74 \pm 0.23$ & $1.77 \pm 0.29$ \\
\hline
\end{tabular}

a: Significant difference vs. non-treated $\mathrm{C} 57 \mathrm{BL} / 6$ mice. b: Significant difference vs, the corresponding saline-treated mice. ${ }^{\circ}$ : Significant difference vs. the corresponding saline- and MAP-treated C57BL/6 mice. " $N$ " represents numbers of animals. 

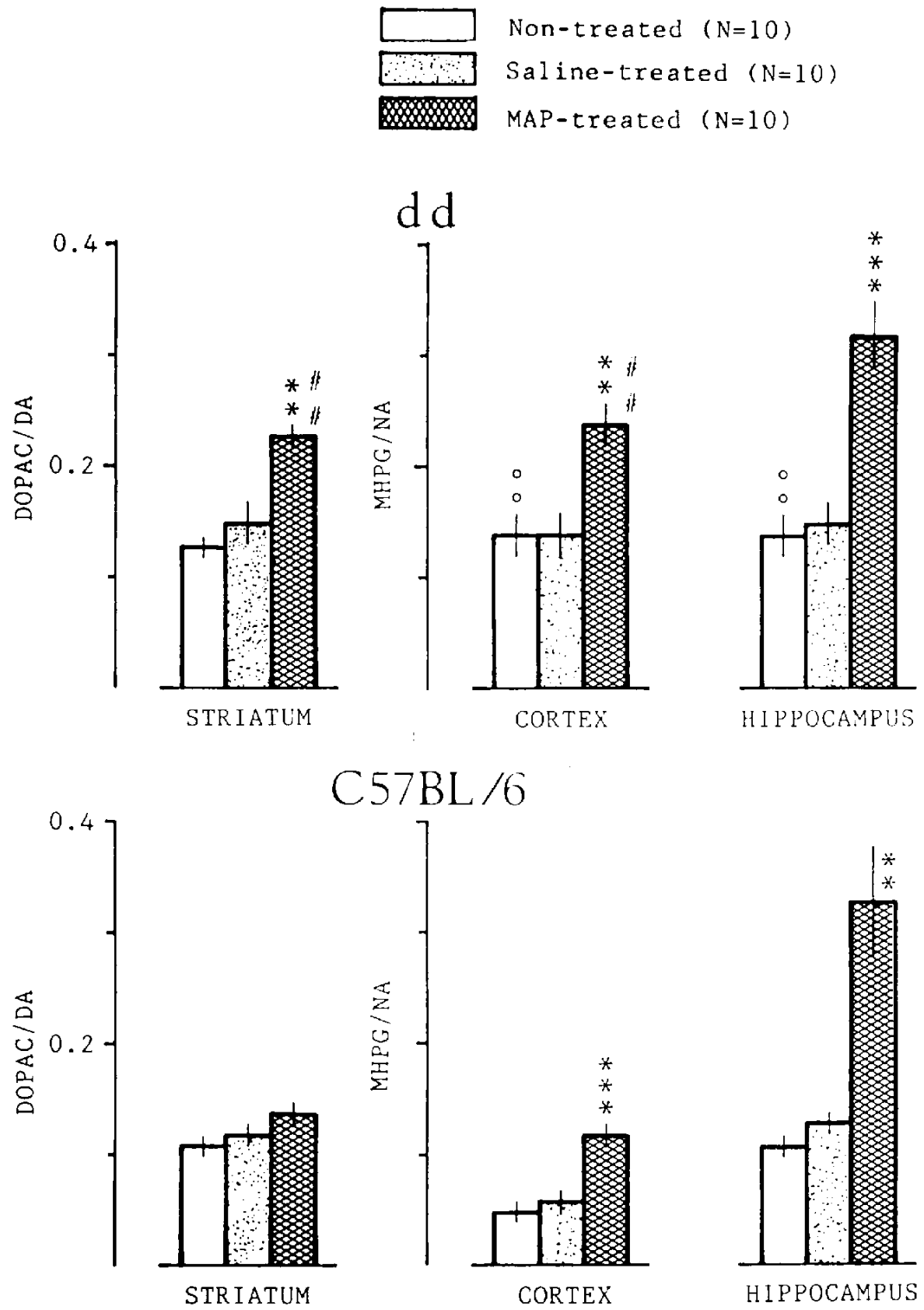

Fig. 2. Effect of repeated administration of methamphetamine (2 $\mathrm{mg} / \mathrm{kg})$ on DOPAC/DA and MHPG/ NA ratios in the mice. Marked increases in DOPAC/DA and MHPG/NA ratios were observed in dd mice, while an increase in MHPG/NA alone was observed in C57BL/6 mice when the drug was repeatedly

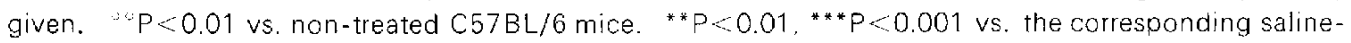
treated mice. ${ }^{\sharp k} \mathrm{P}<0.01$ vs. MAP-treated $\mathrm{C} 57 \mathrm{BL} / 6$ mice. Data are expressed as mean values $\pm \mathrm{S}$. E. " $\mathrm{N}$ " represents numbers of data from which the mean values were calculated. 
No significant differences in DOPAC/DA and MHPG/NA ratios of saline-treated dd and $\mathrm{C} 57 \mathrm{BL} / 6$ mice were observed in any region when compared with those of nontreated mice of the two strains (Fig. 2).

DOPAC/DA ratio in the striatum and MHPG/NA ratios in the cortex and hippocampus significantly increased in MAP. treated dd mice when compared with the corresponding ratios in saline-treated dd mice. In contrast, no significant difference in DOPAC/DA ratio in the striatum was observed between saline- and MAP-treated C57BL/6 mice. However, MHPG/NA ratios in the cortex and hippocampus significantly increased in MAP-treated C57BL/6 mice (Fig. 2).

On the other hand, DOPAC/DA ratio in the striatum and $M H P G / N A$ ratio in the cortex of MAP-treated dd mice were significantly higher than the corresponding ratios in the same regions of MAP-treated C57BL/6 mice. However, no significant difference in MHPG/NA ratio in the hippocampus was seen between MAP-treated mice of both strains (Fig. 2).

\section{Discussion}

The present experiment demonstrated that there was a marked difference in the ambulation-increasing effect of MAP between the two strains. The dd mice responded to the drug more potently than C57BL/6 mice when the $1 \mathrm{st}$ administration was done, although no significant difference in preinjection levels of the ambulatory activities was seen between them. These results are in agreement with the previous results obtained in our laboratory except that the $\mathrm{C} 57 \mathrm{BL} / 6$ mice showed a significantly lower preinjection level of the activity when compared with that in dd mice (23). This discrepancy may be due to a colony difference.

The ambulation-increasing effect of MAP was progressively enhanced in both strains when the drug was given repeatedly, and marked strain difference was also observed in the enhancing effect. According to our experiences, strain differences in the ambulation-increasing effects of MAP or other psychotropic drugs were observed among several strains of mice (12.23). ICR. C $3 \mathrm{H} / \mathrm{He}$ and DBA/2 strains of mice, for example, show a high susceptibility to MAP after both single and repeated administration of the drug. while BALB/c shows a low susceptibility to the same drug. With respect to MAP, strain differences were also demonstrated in the effects of the drug on avoidance response (3) or catecholamine synthesis (24).

In the present experiment, non-treated dd mice exhibited lower maximum densities of ${ }^{3} \mathrm{H}$-SPP and ${ }^{3} \mathrm{H}$-WB4101 binding sites with higher NA turnover in the brain than nontreated $\mathrm{C} 57 \mathrm{BL} / 6$ mice. These results suggest that there is a positive correlation between the ambulation-increasing effect of MAP and NA turnover, but a negative one between the effect and the densities of catecholamine binding sites.

Amphetamines elicit an increase in ambulatory activity in the experimental animals through a stimulation of brain catecholaminergic neurons (25). It has been proposed, for example, that amphetamineinduced increase in ambulatory activity results from an action on noradrenergic neurons, whereas stereotyped behavior is associated with dopaminergic nerve activity (26). In addition, both increases in the ambulatory activity and stereotyped behavior were reported to be associated with dopaminergic nerve activity of the nucleus accumbens and the striatum, respectively (27. 28). Accordingly, it is supposed that strain difference in the ambulation-increasing effect observed in the 1 st administration of MAP is correlated with catecholaminergic nerve activities controlled geneticaly in each strain of mice, in particular brain NA turnover. However, further neurochemical investigations on single administration of MAP would be required to elucidate the mechanism in detail.

In the present experiment, no significant difference in preinjection levels of the ambulatory activities was seen, although marked differences in neurochemical backgrounds were observed between nontreated dd and $\mathrm{C} 57 \mathrm{BL} / 6$ strains of mice. Differences in neurochemical backgrounds, however, are not always reflected directly in animal behaviors according to the parameters used. In many cases, the differences 
can be detected in the behaviors only when the animals are exposed to chemical or physical stimuli such as psychotropic drugs or electric shock. A large number of similar phenomena have been observed in our laboratory (29).

On the other hand, a marked enhancing effect associated with decrease in DA and NA binding sites with increase in their turnover was detected in dd mice following repeated administration of MAP. These results are in agreement with the previous results obtained in rats in our laboratory (19). However, C57BL/6 mice exhibited a minor enhancing effect of MAP. In these mice. marked decrease in NA binding sites with increase in its turnover was also produced by repeated administration of MAP, while the dopaminergic system was scarcely affected. Thus, these results suggest a lower sensitivity of the dopaminergic system to the MAP treatment in C57BL/6 mice.

We have already demonstrated that repeated administration of amphetamines at fixed intervals of $1-7$ days produced marked enhancement of their acute effects on ambulatory activity (reverse tolerance) in mice and rats (30). Our recent findings, furthermore indicated that the enhancing effect of MAP was supposed to have been partially caused by changes in brain catecholaminergic systems, in particular long-lasting increase in catecholamine turnover observed after cessation of the repeated MAP treatment (19). It is, therefore supposed that a similar mechanism is involved in the enhancing effect observed in both strains of mice. The strain difference in the enhancing effect of MAP may be partially produced by different regional sensitivity to MAP between the strains, considering that increase in the ambulatory activity is associated with both dopaminergic and noradrenergic nerve activities as mentioned above.

It has been well-known that the psychotoxic effect of MAP is enhanced by its repeated abuse and that the MAP-abuse frequently produces amphetamine psychosis in human cases (31). On the other hand, it has been reported that there are a number of variables affecting enhancement of the psychotoxic effect of MAP. One of the vari- ables is differences in susceptibility to MAP observed among individuals or among different races (31). The results obtained in the present experiment may demonstrate some qualities in common with biological backgrounds underlying the differences in susceptibility.

Acknowledgment: This research was partially supported by a research fund entitled "Studies on Stimulant Psychosis" from the Japanese Ministry of Welfare and Public Health.

\section{References}

1 Simon, N.G.: The genetics of intermale aggressive behavior in mice: Recent research and alternative atrategies. Neurosci. Biobehav. Rev. 3. 97-106 (1979)

2 Kuribara, H. and Tadokoro, S.: Differences in acquisition of discrete lever-press and shuttle avoidance responses in 6 strains of mice. Japan. J. Pharmacol. 40, 303-310 (1986)

3 Anisman, H.: Differential effects of scopolamine and d-amphetamine on avoidance: Strain interaction. Pharmacol. Biochem. Behav. 3, 809-817 (1975)

4 Cabib, S. and Puglisi-Allegra, S.: Different effects of aporrorphine on climbing behavior and locomotor activity in three strains of mice. Pharmacol. Biochem. Behav. 23, 555-557 (1985)

5 Castellano, C.: Effects of chlorpromazine and imipramine on discrimination learning. consolidation, and learned behavior in two inbred strains of mice. Psychopharmacology (Berlin) 53, 27-31 (1977)

6 Reinhard, J.F., Kosersky, D.S. and Peterson, G.R.: Strain-dependent differences in responses to chronic administration of morphine: Lack of relationship to brain catecholamine levels in mice. Life Sci. 19, 1413-1420 (1976)

7 Marks, M.J., Patinkin, D.M., Artman, L.D., Burch, J.B. and Collins, A.C.: Genetic influences on cholinergic drug response. Pharmacol. Biochem. Behav. 15, 271-279 (1981)

8 Baker, H., Joh, T.H. and Reis, D.J.: Genetic control of number of midbrain dopaminergic neurons in inbred strains of mice: Relationship to size and neuronal density of the striatum. Proc. Natl. Acad. Sci. U.S.A. 77, 4369-4373 (1980)

9 Bochme, R.E. and Ciaranello, R.D.: Dopamine receptor binding in inbred mice: Strain differences in mesolimbic and nigrostriatal dopamine binding sites. Proc. Natl. Acad. Sci. U.S.A. 78, 32553259 (1981) 
10 Kassler, S., Ciaronello, R.D., Shirp, J.G.M. and Barcha, S.J.D.: Genetic variation in activity of enzymes involved in synthesis of catecholamines. Proc. Natl. Acad. Sci. U.S.A. 69, 2448-2450 (1972)

11 Eleftheriou, B.E.: Regional brain norepinephrine turnover rates in four strains of mice. Neuroendocrinology 7, 329-336 (1971)

12 Hayashi, T., Kunihara, $M$. and Tadokoro, S.: Strain differences in the ambulation-increasing effects of psvchotropic drugs in consideration of catecholamine receptors in mice. Japan. J. Pharmacol. 40, 113P (1986)

13 Hirabayashi, M., lizuka, M. and Tadokoro, S.: Simple and easy method of measurement of ambulatory activity in mice. Folia Pharmacol. Japon. 74, 629-639 (1978) (Abs. in English)

14 Growinski, J. and Iversen, L.L.: Regional studies of catecholamines in the rat brain-l. The disposition of ${ }^{3} \mathrm{H}$-dopamine and ${ }^{3} \mathrm{H}$-DOPA in various regions of the brain. J. Neurochem. 13 , $655-669$ (1966)

15 Usdin, T.B., Creese, I. and Snyder, S.H.: Regulation by cations of ${ }^{3} \mathrm{H}$-spiroperidol binding associated with dopamine receptors of rat brain. J. Neurochem. 34, 669-676 (1980)

16 Mita, T., Kuno, T., Nakai, H. and Tanaka, C.: Evidence for the presence of $\mathrm{D}_{2}$ and $5-\mathrm{HT}_{2}$ receptors in the prefrontal cortex. Japan. J. Pharmacol. 32, 1027-1032 (1982)

17 U'Prichard, D.C., Greenberg, D.A. and Snyder, S.H.: Binding characteristics of a radiolabeled agonist and antagonist at central nervous system alpha noradrenergic receptors. Mol. Pharmacol. 13, 454-473 (1977)

18 Williams, L.T. and Lefkowitz, R.J.: Identification and study of alpha-adrenergic receptors by radioligand binding techniques. In Receptor Binding Studies in Adrenergic Pharmacology. p. 53-82, Raven Press. New York (1978)

19 Hayashi, T., Kunihara, M. and Tadokoro, S.: Enhancement of ambulation-increasing effect produced by repeated administration of methamphetamine in rats and neurochemical changes in catecholaminergic neurons. Japan. J. Pharmacol. 43, 283-290 (1987)

20 Lowry, O.H., Rosebrough, N.J., Farr, A.L. and Randall, R.J.: Protein measurement with the Folin phenol reagent. J. Biol. Chem. 193, 265275 (1951)

21 Keller, R., Oke, A., Mefford, I. and Adams, R.N.:
Liquid chromatographic analysis of catecholamines routine assay for regional brain mapping. Life Sci. 19, 995-1004 (1976)

22 Semba, J. and Takahashi, R.: The effect of Lthreo-dihydraxyphenylserine on norepinephrine metabolism in rat brain. Psychiat. Res. 15, 319326 (1985)

23 Kuribara, $H$. and Hirabayashi, M.: Reverse tolerance to psychotropic drugs. Japan. J. Psychopharmacol. 7, 421-439 (1985) (in Japanese)

24 Carr, L.A. and Wehry, S.M.: Effect of cycloheximide and $d$-amphetamine on brain catecholamines in two mouse strains. Pharmacol. Biochem. Behav. 13, 193-197 (1980)

25 Heikkila, R.E., Orlansky, H., Mytilineou, C. and Cohen, G.: Amphetamine: Evaluation of $\mathrm{d}$ - and I-isomers as releasing agents and uptake inhibitors for ${ }^{3} \mathrm{H}$-dopamine and ${ }^{3} \mathrm{H}$-norepinephrine in slices of rat neostriatum and cerebral cortex. J. Pharmacol. Exp. Ther. 194, 47-56 (1975)

26 Taylor, K.M. and Snyder, S.H.: Differential effects of $D$ - and L-amphetamine on behavior and on catecholamine disposition in dopamine and norepinephrine containing neurons of rat brain. Brain Res. 28, 295-309 (1971)

27 Kelly, P.H., Seviour, P.W. and Iversen, S.D.: Amphetamine and apomorphine responses in the rat following 6-OHDA lesions of the nucleus accumbens septi and corpus striatum. Brain Res. 94, 507-522 (1975)

28 Pijnenburg, A.J.J. and Van Rossum, J.M.: Stimulation of locomotor activity following injection of dopamine into the nucleus accumbens. J. Pharm. Pharmacol. 25, 1003-1005 (1973)

29 Hayashi, T., Kunihara, M. and Tadokoro, S.: Behavioral and neurochemical changes produced by postnatal pretreatments with methamphetamine in rats. Japan. J. Pharmacol. $43,17-25$ (1987)

30 Tadokoro, S. and Kuribara, $H$.: Reverse tolerance to the ambulation-increasing effect of methamphetamine in mice as an animal model of amphetamine-psychosis. Psychopharmacol. Bull. 22, 757-762 (1986)

31 Konuma, K.: Multiphasic clinical types of methamphetamine psychosis and its dependence. Psychiat. Neurol. Japan. 86, 315-339 (1984) (in Japanese) 